\title{
Evaluation of antinociceptive potential of methanolic extract of different parts of Ehretia serrata Roxb and Ehretia obtusifolia in vivo.
}

\author{
Zill-E-Huma ${ }^{1}$, Abdur Rauf ${ }^{2}$, Kiran Natasha ${ }^{3}$, Naila Shah ${ }^{4}$, Muhammad Ibrar $^{1}$, Barkatullah ${ }^{5}$, Haroon \\ Khan $^{5}$, Mohammad S. Mubarak ${ }^{6}$, Aneela Maalik ${ }^{7 *}$ \\ ${ }^{1}$ Department of Botany University of Peshawar, Peshawar, Pakistan \\ ${ }^{2}$ Department of Chemistry, University of Swabi, Anbar, Khyber Pakhtunkhwa, Pakistan \\ ${ }^{3}$ Department of Botany, Islamia College University, Peshawar, KPK, Pakistan \\ ${ }^{4}$ Department of Botany, Abdul Wali Khan University, Mardan, KPK, Pakistan \\ ${ }^{5}$ Department of Pharmacy, Abdul Wali Khan University Mardan, Pakistan \\ ${ }^{6}$ Department of Chemistry, the University of Jordan, Amman, Jordan \\ ${ }^{7}$ Department of Chemistry, COMSATS University Abbottabad Campus, 22060-Abbottabad, Pakistan
}

\begin{abstract}
Background: The antinociceptive potential study of different parts of Ehretia serrata Roxb and Ehretia obtusifolia are least explored till now. These plant parts are usually used as fodder and wood in Asia. The aim of this work was to find the antinociceptive effects of the methanolic extracts of leaves, fruits and stem barks of these plants in mice.

Methods: The antinoceceptive activity of methanolic extract of leaf, fruit, and stem bark of $E$. serrata and $E$. obtusifolia in mice was carried out by means of the hot plate method and by using diclofenac sodium as a standard. Twenty groups of $12 \mathrm{~h}$ starved mice were prepared where each group comprised of five mice only. While all these starved mice were allowed free access to clean water. In this study, both male and female Albino mice were used. Analgesiometer was used for this bio-essay.

Results: The results showed that the dose significantly $(\mathrm{P}<0.05)$ reduced the time spent in pain behaviour in all assessment times (0 $\mathrm{min}, 30 \mathrm{~min}$ and $60 \mathrm{~min})$ hence indicating that the plant possesses antinociceptive potential.

Conclusion: It is confirmed through the findings that $E$. serrata and $E$. obtusifloia exhibit strong antinociceptive action in animal model of hot plate which needs verification in other paradigms too.
\end{abstract}

Keywords: Antinociceptive activity, Ehretia serrata, Ehretia obtusifolia, Methanol extracts, Hot-plate method, Glutamate induced nociception.

Accepted on January 23, 2018

\section{Introduction}

Pain is unpleasant sensation or discomfort caused by various factors, and it is an indication of diseases in body or clue to something that is not going well in our body [1]. Control of pain is one of the most important uses of drugs [2]. Drugs, which alter, reduce, or remove the pain sensitivity, are referred to as painkillers or analgesics [3]. Plants contain many bioactive compounds that show significant analgesic activity and reduce pain sensitivity with no harmful effects [4]. The Non-Steroidal Anti-Inflammatory Drugs (NSAIDs) which reduce rheumatism and pain sensation also produce noxious effects such as GIT ulceration and bleeding [2,5]. Investigation and research on different plants lead to synthesis of plants- derived drugs [6]. Natural plant phytochemicals and bioactive compounds from different parts of plant are source of drugs used as an analgesic, anti-depressant and anti-inflammatory agents [7].

Ehretia serrata is an intolerant deciduous tree locally named as Koda in Australia and Puran or Punna in Pakistan [8]. E. serrata is a native species of India and Pakistan [9]. In Pakistan, E. serrata is well distributed in the sub-Himalayan tract from Azad Kashmir westward to Rawalpindi, Islamabad, Murree, Hazara and Swat. It has been successfully planted in areas around Lahore [8]. Timber of Ehretia serrata is used in Assam, Barak valley particularly, North East India as a fuel, leaves are used as a fodder in dist. Kotli, Azad Jammu and Kashmir, whereas bark juice is used for fever [10,11]. The 
green and unripe fresh fruit of Ehretia serrata is used in a form of pickle [12].

Ehretia obtusifolia, on the other hand, is a tiny shrub or bushy tree up to $3 \mathrm{~m}$ height that grows in eastern and southern Africa. It is also found in Pakistan and India [9]. It is found in dry places. This species is locally named as Ghadaboty in KPK and Charmror in Punjab [13]. In Zimbabwe, the leaves of $E$. obtusifolia are used in a mixture to treat throat infection and on gums of infants to relive them from teething pains. The crushed root in porridge is used to cure infertility in women and a mixture of the roots is used to retain placenta. Plant root is taken as an analgesic [14].

Therefore, the current work was conducted to explore the antinociceptive potential of the leaf, fruit, and stem bark of $E$. serrata and E. obtusifolia in animal model of hot plate test.

\section{Materials and Methods}

\section{Preparation of methanol extract}

Different parts of E. serrata and E. obtusifolia such as leaves, fruits, and stem bark were gathered from the Department of Botany, University of Peshawar, Peshawar, Pakistan and were characterized by botanists from herbarium of the Department of Botany, University of Peshawar KPK. The shade-dried leaves, fruit, and stem bark of E. serrata and E. obtusifolia were powdered and then extracted with $99 \%$ methanol by heating under reflux. The filtration of methanolic extract was carried out and the conversion of filtrate to a semisolid mass was brought about by means of rotary evaporation according to the method reported $[15,16]$. For in vivo findings, the extracts were administered orally after mixing them in normal saline. The fresh solutions of the mentioned selected plants were prepared for their use in each experiment.

\section{Experimental animals}

Colony bred Swiss mice from Veterinary Research Institute, Peshawar were used in the research experiments. The animals were placed in Polypropylene (PP) cages and under stable environment and food with free access to clean drinking water.

\section{Acute toxicity test}

The general safety of test articles were carried in acute toxicity as reported elsewhere [17]. The mice were injected with high doses of 500,1500 and $3000 \mathrm{mg} / \mathrm{kg}$ i. p. and observed for gross behavioural and mortality effects during $24 \mathrm{~h}$.

\section{Hot plate method}

The extracts were evaluated for their antinociceptive potential in mice using the hot plate method reported by Shethy et al. and by modified method as well [18]. Twenty groups of $12 \mathrm{~h}$ starved mice were prepared where each group comprised of five mice each. While all these starved mice were allowed free access to clean water. In this study, both male and female Albino mice were used. Analgesometer were used for this bio- essay. Each mouse was placed on a hot plate kept at $55 \pm 10^{\circ} \mathrm{C}$. The initial latency time, which denotes the time taken for mice to show reaction to the pain stimulus determined with a stop watch was recorded. Response to pain stimulus included raising and licking of hind foot or jumping. The cut off time was fixed for $20 \mathrm{~s}$, and served as a control pain reaction time. Response of latency of the animal was noted down in hot plate for three hours with 30-min interval after treatment [19].

\section{Statistical investigation}

The analgesic potential values were expressed as "mean increase in latency after drug administration \pm SEM" in seconds. Statistical analysis was performed with the aid of Student's t-test for significance with the aid of GraphPad Prism-6 (GraphPad Software, San Diego, California USA, http://www.graphpad.com). Differences were considered significant at $p \leq 0.05$ and highly significant at $p \leq 0.01$. The procedure of Alcaraz was followed in all statistical protocols [20].

\section{Results and Discussion}

The main objective of current study was to investigate the analgesic potential of the methanolic extracts of fruit, leaf, and stem bark of E. serrata and E. obtusifolia plants. Presented in Tables 1 and 2 are results of our investigation of the analgesic effect of these extracts in mice. Our findings showed, that the methanol extract of the leaf, fruit, and stem bark of both the plants exhibit pronounced analgesic effect in mice by reducing pain, and that not only the duration but also the intensity, of analgesia induced by different parts were found dosedependent. The significant analgesic effect of methanolic extracts of different plant parts resulted in pain relief. The results showed dose dependency analgesia caused by both intensity and duration of different plant parts methanolic extracts. The complex response to an acute and a noninflammatory nociceptive input is measured through the hot plate test which is normally considered as one of the best models for the evaluation of central nociceptive potential [21]. The prolongation of hot plate latency caused by any agent using the reported test, must be acting centrally as it is considered as an established fact [22]. Thus, the central activity of the methanol plant extracts was investigated. It is important to mention here that not only the peripheral but also the central mechanism of pain is found inhibited by narcotic analgesics [23-25].

Extracts of Ehretia serrata and Ehretia obtusifolia revealed effective analgesic potency at 100, 200 and $300 \mathrm{mg} / \mathrm{kg}$ dose levels as shown in Tables 1 and 2. Results in Table 1 exhibited that the leaf extract of Ehretia serrata show highly significant analgesic activity at $100 \mathrm{mg} / \mathrm{kg}$ dose both after $30 \mathrm{~min}(18.533$ $\pm 3.2353)$ of the test and $(20.186 \pm 2.3695)$ after $1 \mathrm{~h}$. On the other hand, the analgesic activity shown by leaf extract of Ehretia serrata at $200 \mathrm{mg} / \mathrm{kg}$ was $11.446 \pm 0.5217$ ) at $30 \mathrm{~min}$ and highly significant $(22.500 \pm 1.6072)$ after $1 \mathrm{~h}$, whereas at a dose of $300 \mathrm{mg} / \mathrm{kg}$ the leaf extract exhibited more significant result both after $30 \mathrm{~min}(14.333 \pm 1.4529)$ and $(14.766 \pm$ 
Evaluation of antinociceptive potential of methanolic extract of different parts of Ehretia serrata Roxb and Ehretia obtusifolia in vivo

0.8838) after $1 \mathrm{~h}$. Moreover, results showed that the fruit extract of Ehretia serrata at a dose of $100 \mathrm{mg} / \mathrm{kg}$ showed

significant analgesic activity $(14.100 \pm 1.3051)$ at $30 \mathrm{~min}$ and highly significant $(22.430 \pm 0.7605)$ at 1 has given in Table 1 .

Table 1. Analgesic effect of leaf, fruit and stem bark methanol extracts of E. serrata.

\begin{tabular}{|c|c|c|c|c|}
\hline Treatment & Dose (mg/kg) & $\begin{array}{l}\text { Time before dose administration } \\
(0 \mathrm{~min})\end{array}$ & $\begin{array}{l}\text { Time after dose administration } \\
(30 \mathrm{~min})\end{array}$ & $\begin{array}{l}\text { Time after dose administration } \\
(60 \mathrm{~min})\end{array}$ \\
\hline Normal saline & & $70.6667 \pm 4.50925$ & & \\
\hline Dichlofenac sodium & $10 \mathrm{mg} / \mathrm{kg}$ & $9.2667 \pm 0.733$ & $7.00 \pm 0.5773$ & $10.00 \pm 0.57735$ \\
\hline \multirow[t]{3}{*}{ Leaf } & $100 \mathrm{mg} / \mathrm{kg}$ & $8.4667 \pm 0.9955$ & $18.533 \pm 3.2353^{* *}$ & $20.186 \pm 2.3695^{* *}$ \\
\hline & $200 \mathrm{mg} / \mathrm{kg}$ & $7.8333 \pm 0.1202$ & $12.633 \pm 0.3383$ & $22.500 \pm 1.6072^{* *}$ \\
\hline & $300 \mathrm{mg} / \mathrm{kg}$ & $10.546 \pm 2.1641$ & $14.333 \pm 1.4529^{* *}$ & $14.766 \pm 0.8838^{* *}$ \\
\hline \multirow[t]{3}{*}{ Fruit } & $100 \mathrm{mg} / \mathrm{kg}$ & $8.066 \pm 1.01700$ & $14.100 \pm 1.3051^{*}$ & $22.430 \pm 0.7605^{* *}$ \\
\hline & $200 \mathrm{mg} / \mathrm{kg}$ & $10.066 \pm 0.6691$ & $15.50 \pm 0.00000^{* *}$ & $20.253 \pm 0.4511^{* *}$ \\
\hline & $300 \mathrm{mg} / \mathrm{kg}$ & $12.366 \pm 2.1070$ & $13.90 \pm 0.20810^{*}$ & $20.823 \pm 1.4669^{\star *}$ \\
\hline \multirow[t]{3}{*}{ Stem bark } & $100 \mathrm{mg} / \mathrm{kg}$ & $7.800 \pm 0.70000$ & $17.166 \pm 3.7024^{\star *}$ & $21.396 \pm 3.2352^{\star \star}$ \\
\hline & $200 \mathrm{mg} / \mathrm{kg}$ & $7.733 \pm 0.66910$ & $14.666 \pm 0.6227^{* *}$ & $17.89 \pm 0.47480^{*}$ \\
\hline & $300 \mathrm{mg} / \mathrm{kg}$ & $10.633 \pm 2.1987$ & $14.226 \pm 1.2013^{*}$ & $18.386 \pm 1.0123^{* *}$ \\
\hline
\end{tabular}

Values are reported as mean \pm SEM for groups of five animals each. Data were analysed by one way ANOVA followed by Dunnett's test. "Significant at $\mathrm{P}<0.05 ;{ }^{* *}$ Highly significant at $\mathrm{P}<0.01$.

However, at 200 and $300 \mathrm{mg} / \mathrm{kg}$ doses, the fruit extract of $E$. serrata showed significant results $(15.50 \pm 0.00000)$ and $(13.90 \pm 0.20810)$ at $30 \mathrm{~min}$ and highly significant $(20.253 \pm$ 0.4511 and $20.823 \pm 1.4669$ ) after $1 \mathrm{~h}$, respectively (Table 1 ). Results also showed that the analgesic effect of stem bark extract of $E$. serrata at 100 and $200 \mathrm{mg} / \mathrm{kg}$ doses are significant $(17.166 \pm 3.7024$ and $14.666 \pm 0.6227)$ at $30 \mathrm{~min}$ after which the activity began to increase with passage of time and showed more significant results $(21.396 \pm 3.2352$ and $17.89 \pm 0.47480)$ after $1 \mathrm{~h}$ (Table 1$)$.

Ehretia obtusifolia leaf extract showed insignificant analgesic activity at $100 \mathrm{mg} / \mathrm{kg}$ and $200 \mathrm{mg} / \mathrm{kg}$ after $30 \mathrm{~min}$ with the values $10.433 \pm 0.3844$ and $11.446 \pm 0.5217$ ), respectively, whereas and highly significant effects were observed after $1 \mathrm{~h}$ $(19.900 \pm 1.9157$ and $17.506 \pm 0.1189)$ as displayed in Table 2 .

Table 2. Analgesic effect of leaf, fruit, and stem bark methanol extracts of E. obtusifolia.

\begin{tabular}{|c|c|c|c|c|}
\hline Treatment & Dose (mg/kg) & $\begin{array}{l}\text { Time before dose administration } \\
(0 \mathrm{~min})\end{array}$ & $\begin{array}{l}\text { Time after dose administration } \\
(30 \mathrm{~min})\end{array}$ & $\begin{array}{l}\text { Time after dose administration } \\
(60 \mathrm{~min})\end{array}$ \\
\hline Normal saline & & $70.6667 \pm 4.50925$ & & \\
\hline Dichlofenac sodium & $10 \mathrm{mg} / \mathrm{kg}$ & $9.2667 \pm 0.733$ & $7.00 \pm 0.5773$ & $10.00 \pm 0.57735$ \\
\hline \multirow[t]{3}{*}{ Leaf } & 100 mg/kg & $7.833 \pm 0.4409$ & $10.433 \pm 0.3844$ & $19.900 \pm 1.9157^{* *}$ \\
\hline & 200 mg/kg & $9.000 \pm 0.7211$ & $11.446 \pm 0.5217$ & $17.506 \pm 0.1189^{*}$ \\
\hline & $300 \mathrm{mg} / \mathrm{kg}$ & $7.833 \pm 0.6119$ & $17.496 \pm 3.0343^{* *}$ & $25.273 \pm 1.1042^{* *}$ \\
\hline \multirow[t]{3}{*}{ Fruit } & 100 mg/kg & $12.266 \pm 1.092$ & $16.056 \pm 0.9032^{* *}$ & $20.220 \pm 2.8853^{\star *}$ \\
\hline & $200 \mathrm{mg} / \mathrm{kg}$ & $9.566 \pm 1.0520$ & $13.2900 \pm 0.531^{*}$ & $14.056 \pm 2.2420^{*}$ \\
\hline & $300 \mathrm{mg} / \mathrm{kg}$ & $10.33 \pm 1.1623$ & $14.890 \pm 0.8083^{*}$ & $12.666 \pm 0.4409$ \\
\hline \multirow[t]{3}{*}{ Stem bark } & $100 \mathrm{mg} / \mathrm{kg}$ & $8.400 \pm 0.3000$ & $18.223 \pm 1.7410^{\star *}$ & $23.733 \pm 2.8591^{\star \star}$ \\
\hline & $200 \mathrm{mg} / \mathrm{kg}$ & $7.466 \pm 0.8570$ & $13.766 \pm 3.3448^{*}$ & $17.466 \pm 3.0168^{* *}$ \\
\hline & $300 \mathrm{mg} / \mathrm{kg}$ & $11.166 \pm 1.833$ & $12.456 \pm 0.7919^{*}$ & $20.536 \pm 2.2838^{* *}$ \\
\hline
\end{tabular}

Values are reported as mean \pm SEM for groups of five animals each. Data were analyzed by one way ANOVA followed by Dunnett's test. "Significant at $P<0.05 ;{ }^{* *} H i g h l y$ significant at $\mathrm{P}<0.01$ 
The pain killing effect of leaf increases as time and dose increase. On the other hand, leaf extract of Ehretia obtusifolia at a dose of $300 \mathrm{mg} / \mathrm{kg}$ showed highly significant after $30 \mathrm{~min}$ and $1 \mathrm{~h}$ with the values $17.496 \pm 3.0343$ and $25.273 \pm 1.1042$ respectively. The Fruit extract displayed highly significant results at 100 a dose of $\mathrm{mg} / \mathrm{kg}$ both after $30 \mathrm{~min}$ and $1 \mathrm{~h}$ with the values $16.056 \pm 0.9032$ and $20.220 \pm 2.8853$ respectively, whereas at 200 and $300 \mathrm{mg} / \mathrm{kg}$ doses, significant results with the values $13.2900 \pm 0.531$ and $14.890 \pm 0.8083$, respectively, after $30 \mathrm{~min}$ were obtained, and after $1 \mathrm{~h}$ the values were $14.890 \pm 0.8083$ and $12.666 \pm 0.4409$. Stem bark of Ehretia obtusifolia showed highly significant values at level of 100 $\mathrm{mg} / \mathrm{kg}$ both after $30 \mathrm{~min}$ and $1 \mathrm{~h}$ with the values $18.223 \pm$ $1.7410,23.733 \pm 2.8591$, respectively, as shown in Table 2 . At 200 and $300 \mathrm{mg} / \mathrm{kg}$ doses the values were13.766 \pm 3.3448 and $12.456 \pm 0.7919$ after $30 \mathrm{~min}$ of administration, and were $17.466 \pm 3.0168$ and $20.536 \pm 2.2838$, respectively after $1 \mathrm{~h}$. The glutamate was found to play a significant role in nociceptive processing in central as well as in peripheral nervous systems, therefore, the effect of Ehretia obtusifolia against nociception induced by glutamate is of great interest [26].

\section{Conclusion}

The present results indicate that the methanolic extract of leaf, fruit, and stem bark of E. serrata and E. obtusifolia have significant analgesic effects. The extract will, therefore, be of possible potential benefit in the control of pain. However, more detailed studies are required to establish the safety, efficacy, and active constituents of these plants, along with the mechanism of action.

\section{Acknowledgement}

Author (A. Rauf) is grateful to Higher Education Commission (HEC) of Pakistan for award of research start up grant No 21:619/SRGP/R \& D/HEC/2014.

\section{Conflict of Interest}

No conflict of interest is declared among authors.

\section{References}

1. Srineeraja P, Lakshmi T. Antinociceptive activity of traditional Chinese medicinal plants. Int J Pharm Sci Rev Res 2013; 23: 53-57.

2. Rang HP, Dal MM, Ritter JM, Moore PK. Pharmacology, 5th edition. Elsevier Science, New Delhi, India 2003.

3. Raquibul SM, Hossain MM, Aktar R, Jamila M, Mazumde MEH, Alam MA. Analgesic activity of the different fractions of the aerial parts of Commenilabenghalensis Linn. Int J Pharmacol 2010; 6: 63-67.

4. Ripa FA, Dash PR, Faruk O. CNS depressant, analgesic and anti-inflammatory activities of methanolic seed extract of Calamusrotang Linn. fruits in rat. J Pharm Phytochem 2015; 3: 121-125.

5. Tapiero H, Ba GN, Couvreur P, Tew KD. Polyunsaturated Fatty Acids (PUFA) and eicosanoids in human health and pathologies. Biomed Pharmacother 2002; 56: 215-222.

6. Onzago RO, Kiama SG, Mbaria JM, Gakuya DW, Githiji CG, Rukenya ZM. Analgesic activity of aqueous extract of Vernoniahymenolepis (A. Rich) a traditional medicine plant used in Kenya for toothache. The J Phytopharmacol 2013; 2: 41-45.

7. Suleiman MM, Mamman M, Naidoo V, Tauheed M, Eloff JN. Anti-inflammatory and antinociceptive activities of Loxostylisalata A. Spreng. Exrchb (Anacardiaceae). Am J Res Comm 2003; 2: 227-246.

8. Shetty SN, Anika SM. Laboratory manual of pharmacology and toxicology fourth dimension. Publishers Enugu, Nigeria 1982; 8-13, 87-90.

9. Ali SI, Nasir YJ. Flora of Pakistan nos. 191-193. Univ Karachi Nat Herbarium 1991.

10. Das T, Das AK. Inventorying plant biodiversity in home gardens: A case study in Barak Valley, Assam, North East India. Current Sci Bangalore 2005; 89: 155.

11. Ajaib M, Zaheer-ud-din Z. Ethnobotanical studies of useful trees of district Kotli, Azad Jammu and Kashmir. Biologia Pak 2014; 60: 63-71.

12. Haq FU, Ahmad H, Alam M. Species diversity of vascular plants of Nandiar valley western Himalaya, Pakistan. Pak J Bot 2010; 42: 213-229.

13. Iqbal I, Hamayun M. Studies on the traditional uses of plants of Malam Jabba valley, District Swat, Pakistan. Ethnobot Leaflet 2005; 1: 32.

14. Schmelzer GH, Gurib-Fakim A. Plant resources of tropical Africa. PROTA Foundation 2008; 153-158.

15. Rauf A, Khan A, Uddin N, Akram M, Arfan M, Uddin G, Qaisar M. Preliminary phytochemical screening, antimicrobial and antioxidant activities of Euphorbia milli. Pak J Pharm Sci 2014; 27: 947-951.

16. Rauf A, Uddin G, Khan H, Arfan M, Siddiqui BS. Bioassay-guided isolation of antibacterial constituents from Diospyros lotus roots. Nat Prod Res 2015; 29: 2318-2329.

17. Khan H, Saeed M, Gilani AUH, Khan MA, Dar A, Khan I. The antinociceptive activity of Polygonatumverticillatum rhizomes in pain models. J Ethnopharmacol 2010; 127: 521-527.

18. Franzotti EM, Santos CVF, Rodrigues HMSL, Mourao RHV, Andrade MR, Antoniolli AR. Anti-inflammatory, analgesic activity and acute toxicity of Sida cordifolia L. (Malva-branca). J Ethnopharmacol 2000; 72: 273-277.

19. Okokon JE, Nwafor PA. Anti-inflammatory, analgesic and antipyretic activities of ethanolic root extract of Croton zambesicus. Pak J Pharm Sci 2010; 23: 383-390.

20. Alcaraz MJ, Jimenez MJ. Anti-inflammatory compounds from Sideritisjavalambrensis n-hexane extract. J Nat Prod 1989; 52: 1088-1091. 
obtusifolia in vivo

21. Sabina EP, Chandel S, Rasool MK. Evaluation of analgesic, antipyretic and ulcerogenic effect of Withaferin A. Int J Integrative Bio 2009; 6: 52-56.

22. Ibironke GF, Ajiboye KI. Studies on the antiinflammatory and analgesic properties of Chenopodiumambrosioides leaf extract in rats. Int $\mathrm{J}$ Pharmacol 2007; 3: 111-115.

23. Elisabetsky E, Amador TA, Albuquerque RR, Nunes DS, Cavalho ACT. Analgesic activity of psychotriacolorata (Wild ex R and S). muell arg. Alkaloids. J Ethno Pharmacol 1995; 48: 7783.

24. Pal S, Sen T, Chaudhuri AK Neuropsychopharmacological profile of the methanolic fraction of Bryophyllumpinnatum leaf extract. J Pharm Pharmacol 1999; 51: 313-318.

25. Ahmed F, Hossain MH, Rahman AA, Shahid IZ. Antinociceptive and sedative effects of the bark of
Cerberaodollam Gaertn. Orient Pharm Exp Med 2006; 6: 344-348.

26. Ferreira J, Silva DGL, Calixto JB. Contribution of vanilloid receptors to the overt nociception induced by $\mathrm{B} 2$ kinin receptor activation in mice. Br J Pharmacol 2004; 141: 787-794.

\section{*Correspondence to}

Aneela Maalik

Department of Chemistry

COMSATS Institute of Information Technology

Abbottabad Campus

Pakistan 